\title{
Annual changes of aerosol optical depth and Ångström exponent
}

\author{
over Spitsbergen \\ P. Pakszys ${ }^{1}$, T. Zielinski ${ }^{1,3}$, K. Markowicz ${ }^{2}$, T. Petelski ${ }^{1}$, P. Makuch ${ }^{1}$, J. Lisok ${ }^{2}$, M. \\ Chilinski ${ }^{2}$, A. Rozwadowska ${ }^{1}$, Ch. Ritter ${ }^{4}$, R. Neuber ${ }^{4}$, R. Udisti ${ }^{5}$, M. Mazzola ${ }^{5}$ \\ ${ }^{1}$ Institute of Oceanology, Polish Academy of Sciences \\ ${ }^{2}$ University of Warsaw, Poland \\ ${ }^{3}$ Centre for Polar Studies National Leading Research Centre, 60 Bedzinska Street, 41-200 \\ Sosnowiec, Poland \\ ${ }^{4}$ Alfred-Wegener-Institute Helmholtz-Centre for Polar- and Marine Research, Potsdam, \\ Germany \\ ${ }^{5}$ University of Florence, Italy
}

KEY WORDS: Atmospheric aerosols; Aerosol optical properties; Sun photometry; Spitsbergen; iAREA; GAME

\section{ABSTRACT:}

In this work we present the annual changes of two major, climate related aerosol optical parameters measured at three Spitsbergen locations, Ny-Alesund, Longyearbyen and Hornsund over a period between 2000 and 2012. We discuss the changes of aerosol optical depth (AOD) at $500 \mathrm{~nm}$ and the Ångström exponent (AE) (440-870 nm) measured with use of different types of sun photometers. For the measurement data we adopted several data quality assurance techniques and the calibration of the instruments was taken into consideration. The results obtained show that marine source has been a dominating of aerosol sources over Spitsbergen. Some years (2005, 2006, 2008 and 2011) show very high values of AOD due to strong aerosol events such as the Arctic Haze. In general the mean AOD values increase over the period of 2000 and 2012 over Spitsbergen. This may indicate the presence of larger scale of atmospheric pollution in the region.

\section{Introduction}

The Arctic region is especially sensitive to climate change and its climate is modulated, in part, by atmospheric aerosols that affect the distribution of radiative energy passing through the atmosphere (Rozwadowska et al., 2012). Aerosols affect the surfaceatmosphere radiation balance directly through interactions with solar and terrestrial radiation and indirectly through interactions with cloud particles. In Polar regions, where the surface albedo can exceed 0.85 (in VIS) in snow and ice covered areas, aerosols may cause significant warming at the ground (Tomasi et al., 2007; Engval et al., 2008). While such effects are due mainly to the direct scattering and absorption of incoming solar radiation, exchanges of thermal radiation between the surface and the atmosphere enhance heating below aerosol layers (Stohl, 2006, Fischer et al., 2010).

Atmospheric aerosols originate from a wide variety of sources in both marine and continental environments and their content varies significantly depending upon the air mass source and history (Peteleski et al.,2014). These species are, in general, poorly accounted for 
in climate models. Better quantification of the radiative forcing by different types of aerosol is needed to improve predictions of future climate (Brock et al., 2011).

During the last century the temperature increase in the Arctic has been observed to be larger than the global average (IPCC, 2013). The reason for this "Arctic amplification" relates to both the complex feedbacks that are active in the Arctic environment as well as the overall environmental conditions that are characteristic of the Arctic environment (Quinn et al., 2007). This increased warming results in positive feedback which further impacts the radiative balance via reduced surface albedo (Hudson, 2011). Future changes in the Arctic are projected to progress rapidly and the projections show that the Arctic Ocean may be seasonally ice free in the next several decades. This will result in a more pronounced impact on atmospheric aerosol sources and sinks and on cloud properties and their distribution in the area (Petelski and Piskozub, 2006).

Methods commonly used for monitoring atmospheric pollution (including aerosols) are optical ones, which collect data from a given point or a small area (Labow, 1996; Dixon, 1998; Drollette, 2000; Smirnov et al., 2002). Studies using ground-based sunphotometry are very effective in investigations of aerosol optical properties. Aerosol optical depth measured at different wavelengths is one of the key parameters in aerosol studies (Dubovik et al., 2002; Zielinski, 2004; Markowicz et al., 2008; Mazzola et al., 2012; Zielinski et al., 2012). Also satellite remote sensing is a good approach to obtain the aerosol information over the Arctic region, for which appropriate aerosol models are required.

In this paper we describe the aerosol optical depth and Ångström exponent values measured at three locations in Spitsbergen. These stations include Hornsund in the south of the island, Longyearbyen in the center of the island and $\mathrm{Ny}$-Alesund, in the north.

\section{Site characteristics and instrumentation}

\subsection{Station characteristics}

The climate of Svalbard is dominated mostly by its northerly location, while the Norwegian Current and West Spitsbergen Current (which are a continuation of the North Atlantic Current) moderate its temperatures. The Arctic climate is the place where cold polar air from the north and west (high pressure over Greenland and the Polar basin) meets mild, wet sea air from the south (low pressure between Greenland and Spitsbergen )(Treffeisen et al., 2011; Rozwadowska et al., 2010). As a result very active cyclonic circulation (and fronts with cloudy conditions, rain and strong winds are often reported in this region. These are major factors which determine the changeable weather over Svalbard, which in various parts of the archipelago is significantly different. The western part is warmer, while the interior has relatively more continental climate than the coasts.

Three sites in Spitsbergen are taken into consideration and they include all available AERONET (AErosol RObotic NETwork) data over Svalbard (http://aeronet.gsfc.nasa.gov/). These include stations in Hornsund $\left(77^{\circ} 00^{\prime} 03^{\prime \prime} \mathrm{N}, 15^{\circ} 33^{\prime} 36^{\prime \prime} \mathrm{E}\right.$, at $10 \mathrm{~m}$ a.s.1), Longyearbyen $\left(78^{\circ} 13^{\prime} 12^{\prime} \mathrm{N}, 15^{\circ} 38^{\prime} 56^{\prime \prime} \mathrm{E}\right.$, at $30 \mathrm{~m}$ a.s.1.) and Ny-Alesund $\left(78^{\circ} 55^{\prime} 44^{\prime \prime} \mathrm{N}, 11^{\circ} 51^{\prime} 39^{\prime \prime} \mathrm{E}\right.$, at $46 \mathrm{~m}$ a.s.1.) (Figure 1).

Ny-Alesund is the highest above sea level and most northerly situated station located on Brøggerhalvøya and Kongsfjorden. The village is surrounded by mountains and tundra system. The Svalbard capital town of Longyearbyen - in the middle part of the island, is situated in the valley of Longyeardalen and on the shore of Adventfjorden. Hornsund is the southernmost fjord of the western side of Spitsbergen. The location of the stations has significant impact on the differentiation of air masses moving to the study area. 


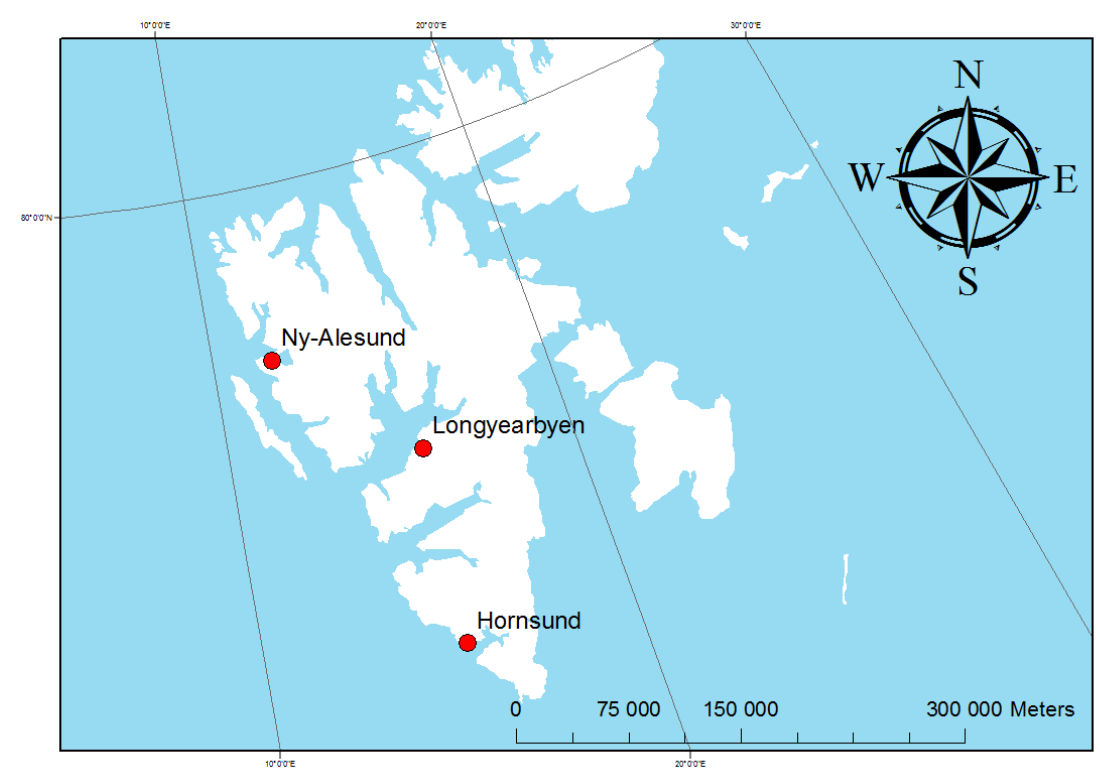

Figure 1. Location of the research stations in Spitsbergen.

The AERONET network provides long-term, globally distributed observations of spectral aerosol optical depth (AOD) as well as Ångström exponent (AE). Ground-based remote sensing techniques are used to obtain long-term and continuous characterization of aerosols over the whole world.

In Ny-Alesund observations have also been performed in the AWIPEV (FrenchGerman Arctic Research Base at Koldeway station, Ny-Alesund) (http://www.awipev.eu/) (Herber et al., 2002). Since 2001 the Institute of Oceanology Polish Academy of Sciences (IOPAN) has performed their aerosol studies in the same area as the AERONET, i.e. in Longyearbyen, Hornsund and Ny-Alesund.

\subsection{Instruments and database characteristics}

The database used in this paper is composed of measurements performed in three different areas of Spitsbergen (Hornsund, Longyearbyen, Ny-Alesund) and different sun photometers as well as for different time intervals. The instrument and data information are provided in Table 1 below.

Table 1. Instruments and information on data availability.

\begin{tabular}{|l|l|l|l|l|c|}
\hline No. & Site/Station & \multicolumn{1}{|c|}{ Instrument } & Reference & $\begin{array}{c}\text { Data } \\
\text { availability }\end{array}$ & $\begin{array}{c}\text { Number of } \\
\text { measurement } \\
\text { days }\end{array}$ \\
\hline \multirow{2}{*}{1} & Hornsund & Cimel CE-318 & AERONET & $2005-2012$ & 435 \\
\cline { 3 - 6 } & M-II & IOPAN & $2009-2012$ & 9 \\
\hline 2 & Longyearbyen & Cimel CE-318 & AERONET & $2003-2004$ & 78 \\
\hline 3 & Ny-Alesund & Cimel CE-318 & AERONET & 2006 & 9 \\
\cline { 2 - 6 } & Ny-Alesund, & SP1A & AWIPEV & $2000-2011$ & 594 \\
\cline { 2 - 6 } & Ny-Alesund & M-II & IOPAN & $2001-2012$ & 13 \\
\hline
\end{tabular}


For all locations we use data from a period of March 2000 to September 2012. At the Svalbard latitude sunphotometric measurements cannot be performed all year round due to the polar night. At these latitudes the sun does not rise between late September and early March. We accepted the approach that when sun is over the horizon for a period shorter than 10 hours per day and during the polar night we have winter and autumn. Summer is defined for days when sun occurs for an entire day while, spring - for more than 10 hours a day and only for measurements which were carried out before the defined summer. Such an approach resulted in a reduced number of data. We use data from only spring and summer months. Secondly, only clear sky conditions enable to make any solar measurements and thus the number of "good" measurement days is also limited.

The AERONET protocols impose standardization of instruments, data quality, processing and calibration (Holben et al., 1998). The measurements are acquired with Cimel sun photometer CE-318. This automatic sun and sky radiometer has spectral interference filters centered at selected wavelengths: 340, 380, 440, 500, 670, 870, 1020 and $1640 \mathrm{~nm}$. The real time operation of the data acquisition and motion steering are controlled by microprocessors. Sequence of the measurements is provided automatically every clear day, every 15 minutes (Holben et al., 1998). The data accuracy is 0.01 (visible solar radiation) or 0.02 (ultraviolet) (Smirnov et al., 2000). The AERONET provides tree levels of data: level 1.0 (raw data), level 1.5 (cloud-screened data) and level 2.0 (quality-assured data). For the detailed description see AERONET website (http://aeronet.gsfc.nasa.gov/).

The IOPAN based data obtained with a Microtops II sunphotometer were collected and processed with the pre - and post - field calibration, automatic cloud clearing and were manually inspected. These portable instruments made by Solar Light Company are capable of measuring the total ozone column, total precipitable water vapor and aerosol optical depth (Morys et al., 2001; Ichoku et al., 2002). Each of these parameters is automatically derived by the instrument from equations installed by the manufacturer. The Microtops II instruments currently in use at the IOPAN have five channels, but they may have one of two configurations: $340,440,675,870,936 \mathrm{~nm}$ or $440,500,675,870$, and $936 \mathrm{~nm}$. The estimates of uncertainty of the AOD in each channel oscillates around 0.02. Detailed instrument description is available at the AERONET webpage (http://aeronet.gsfc.nasa.gov) and has been presented by Markowicz et al., (2012) and Zawadzka et al., (2014).

In this paper, we also used the data from Koldeway Station in Ny-Alesund performed by AWIPEV. Data from 2000 until 2012 were obtained using a full-automatic sun photometer type SP1A produced by Dr. Schulz and Partner GmBH. The instrument covers a spectral range from $350 \mathrm{~nm}$ to $1050 \mathrm{~nm}$ in 17 channels. It automatically tracks the sun, which ensures continuity of the measurements. The AOD uncertainty is 0.01 (Toledano et al., 2012).

\section{Methodology}

The AOD is a key parameter in aerosol studies which describes the entire atmospheric column and is derived from the Beer-Bouger-Lambert law. In case of Cimel and SP1A sun photometers the AOD is obtained using the following algorithm. The total optical depth of the atmosphere $(\tau)$ is obtained from the absolute direct signal from the ground level $(S(\lambda))$ :

$S(\lambda)=S_{0}(\lambda) \cdot e^{(-\tau m)}$

where: $S_{0}(\lambda)$ is signal at the top of the atmosphere (with earth-sun distance correction), m air mass. The AOD $\left(\tau_{a}\right)$ is obtained after subtraction of the Rayleigh optical depth $\left(\tau_{R}\right)$, contribution and ozone optical depth $\left(\tau_{O_{3}}\right)$ for the $670 \mathrm{~nm}$ channel: 
$\tau_{a}=\tau-\tau_{R}-\tau_{O_{3}}$

The Ångström Exponent (AE) is indicative of the size predominance. From spectral AOD at channels 440, 670 and $870 \mathrm{~nm}$ data are calculated AE:

$\tau_{a}(\lambda)=\beta(\lambda)^{-\alpha}$

The final post-processing data including sequencing, cloud-screening is carried out with the AERONET protocols (Smirnov et al., 2000).

The Microtops II calculates the AOD value at each wavelength based on the channel's signal, its extraterrestrial constant, atmospheric pressure (for Rayleigh scattering), time and location. Solar distance correction is automatically applied. All optical depth calculations are based on the Bouguer-Lambert-Beer law. The AOD formula is as follows:

$A O T_{\lambda}=\frac{\ln \left(V_{0 \lambda}\right)-\ln \left(V_{\lambda} \cdot S D C O R R\right)}{m}-\tau_{R} \cdot \frac{P}{P_{0}}$.

where: $\ln \left(V_{0 \lambda}\right)$ is the AOD calibration constant, $V_{\lambda}$ is the signal intensity in [mV], SDCORR is the mean Earth-Sun distance correction, $\mathrm{m}$ is the optical air mass, $\tau_{R}$ is the Rayleigh optical depth, and $\mathrm{P}$ and $\mathrm{P}_{0}$ are station pressure and standard sea-level pressure $(1013.25 \mathrm{mB})$, respectively (Morys et al., 2001).

Typically, aerosol optical depths are derived from ground-based techniques. Sun photometer is a standard instrument which gives the integral for the total atmospheric column. This is the first step to build up the parameters which will determine the aerosol optical characteristics.

In our analyses we used Level 2.0 data. Such choice has already limited our data to those which have already been cloud-screened and quality assured. As a result we have obtained a total of 522 days and 11387 measurements from all stations.

We present the AOD data only at a wavelength of $500 \mathrm{~nm}$. We characterized the slope of these spectra characteristics by the Ångström Exponent, which is the function of the particle size distribution. It is calculated for the range $440-870 \mathrm{~nm}$ according to the AERONET protocol.

The presence of clouds is not always possible to detect, especially with thin Cirrus clouds or drifting snow crystals (Rozwadowska and Sobolewski, 2010). Thus the data were also manually inspected with meteorological observation (WMO, MODIS) if necessary. This strategy was also followed with the Microtops II data.

For the IOPAN measurements we adopted a similar strategy to that of the AERONET. Data were collected during the IOPAN routine, annual expeditions (AREX-Arctic Expedition) or during dedicated campaigns within the scope of the research projects, such as e.g. iAREA (http://polandaod.pl/). IOPAN data were recalibrated with the strategy presented in the instrument User Guide and according to the Ichoku et al. (2002). Data were recalculated based on formula 4. Then the detection of clouds was checked with the satellite and the WMO. Data with presence of cirrus clouds were rejected. From each series of 5 shots only the lowest value was used. Sequencing the data into series of five "shots" with two minutes time limit allows to improve the quality of the data after choosing the best result.

The SP1A instruments operated at the AWIPEW station are calibrated in October at Zugspitze or in February at Izana/Tenerife, Spain using the well-known Langley procedure for solar applications (Shaw, 1976). More details are available in Herber et al. (2002). Data from SP1A contain 594 days in 159273 measurements. The AWIPEV data were cleared from 
instrument's error and a computational algorithm has been applied, in which we analyzed the 'suspect' data (errors, clouds, snowstorms, etc.). The 'suspect' data meet the following conditions:

1) $\mathrm{AOD}>0.1$

In this case each AOD point which meets such criterion is classified as an event (haze, pollution, clouds etc.),

2) $\left|\mathrm{AOD}_{2}-\mathrm{AOD}_{1}\right| \geq 0.04$

In this case data when absolute value of the difference between successive measurements during the same day is higher or equals 0.04 has been chosen. This condition filters out Arctic Haze from the selected data. The expected variability of an Artic Haze is very low during all analyzed events (AOD values are stable).

3) $\operatorname{STD}_{\mathrm{AOD}} \geq 0.02$

Similar condition which informs about daily variability. Only the days which meet the previous conditions and with standard deviation higher or equal 0.02 have been left in this step.

After these 3 steps we were checking if the dates did not cover dates of data from other instruments. Only different dates have been left. The extracted data were evaluated with respect to Cloud - Aerosol Lidar and Pathfinder Satellite Observation (CALIPSO), MODIS data and also with the World Meteorological data for weather station in Ny-Alesund.

Similar conditions were adopted for the Angstrom exponent:

1. $\mathrm{AE} \geq-0.2 \& \mathrm{AE} \leq 2$

In this case we selected the Angstrom exponent with extreme values, which could be a systematic error of instruments, especially for the SP1A for four years of measurements.

\section{2. $\left|\mathrm{AE}_{2}-\mathrm{AE}_{1}\right| \geq 2$}

Difference between successive measurements as an absolute value during the same day higher or equals 2 . Chosen values are very unusual during the same day with stable values of AOD.

$$
\text { 3. } \mathrm{AE}_{\text {mean }}-2 \mathrm{AEi} \geq 2
$$

Difference between mean value of the AOD and double variable value higher than 2 . This condition selects outliers from the mean AE value.

\section{Results and discussion}

Looking more closely in the data we distinguished those for which AOD exceed 0.1. Those data were used for the classification of events:

1)AOD $>\mathrm{MEAN}_{\mathrm{AOD}}+\mathrm{STD}_{\mathrm{AOD}}$ as an event

2) $\mathrm{AOD}>\mathrm{MEAN}_{\mathrm{AOD}}+4 \mathrm{STD}_{\mathrm{AOD}}$ as an extreme event

Such analyses allowed for the specification of the occurrence of $5.27 \%$ of events in the entire data set. It gives a total of 8326 out of 157847 data rows. Extreme events account for $2.35 \%$ of the data (3720 cases), and most of them occurred in 2003, 2006, 2008 and 2010.

While AOD gives information about the aerosol loading, the AE is elated to aerosol size (type). The distribution of scatterplot enables to identify aerosol sources and size distribution (Toledano, 2007). For that purpose we have prepared a scatter plot of AOD versus AE with information of number of measurements. Aerosols can be divided into the following types: 
1. Marine aerosols

The pure marine should be located in the region with AOD < 0.15 and AE 0.5-1.7. This type is confined to the so-called accumulation mode and is present above the oceanic areas. The potential transport of continental aerosols over maritime environments interferences with this type of particles, which changes density and particle size distribution.

2. Continental and biomass burning aerosols

Continental origin aerosols are also expected at coastal sites. This type mainly consists of fine particles ( $<2.5$ micrometers), and presents high values of AE (above 1). The AOD is very variable and depends on the weather conditions (mostly around 0.15-0.30, and that aerosols could be less or more polluted (AOD>2.5 during e.g. forest fires etc.). Biomass burning aerosols are characterized by turbid atmosphere and large values of the AOD are reported.

3. Desert Dust aerosols

Particles are characterized by very turbid atmosphere. Very similar values of AOD result in low AE values. The AOD increase from $0.2-0.3$ up to 1.2 against decreasing values of AE from 1 to 0.

\section{Mixed types of aerosols}

Coastal and marine produce a mixed type - with typical AOD $<0.15$ and AE 0.3-0.6.

In Figure 2 we present all AOD and AE data collected between 2000 and 2012 in all three Spitsbergen locations, Ny-Alesund, Longyearbyen and Hornsund altogether. The data have been collected in spring and summer seasons. In Figure 3 we show a scatter plot of AOD $(500 \mathrm{~nm})$ versus $\mathrm{AE}$ for all data from the discussed stations.
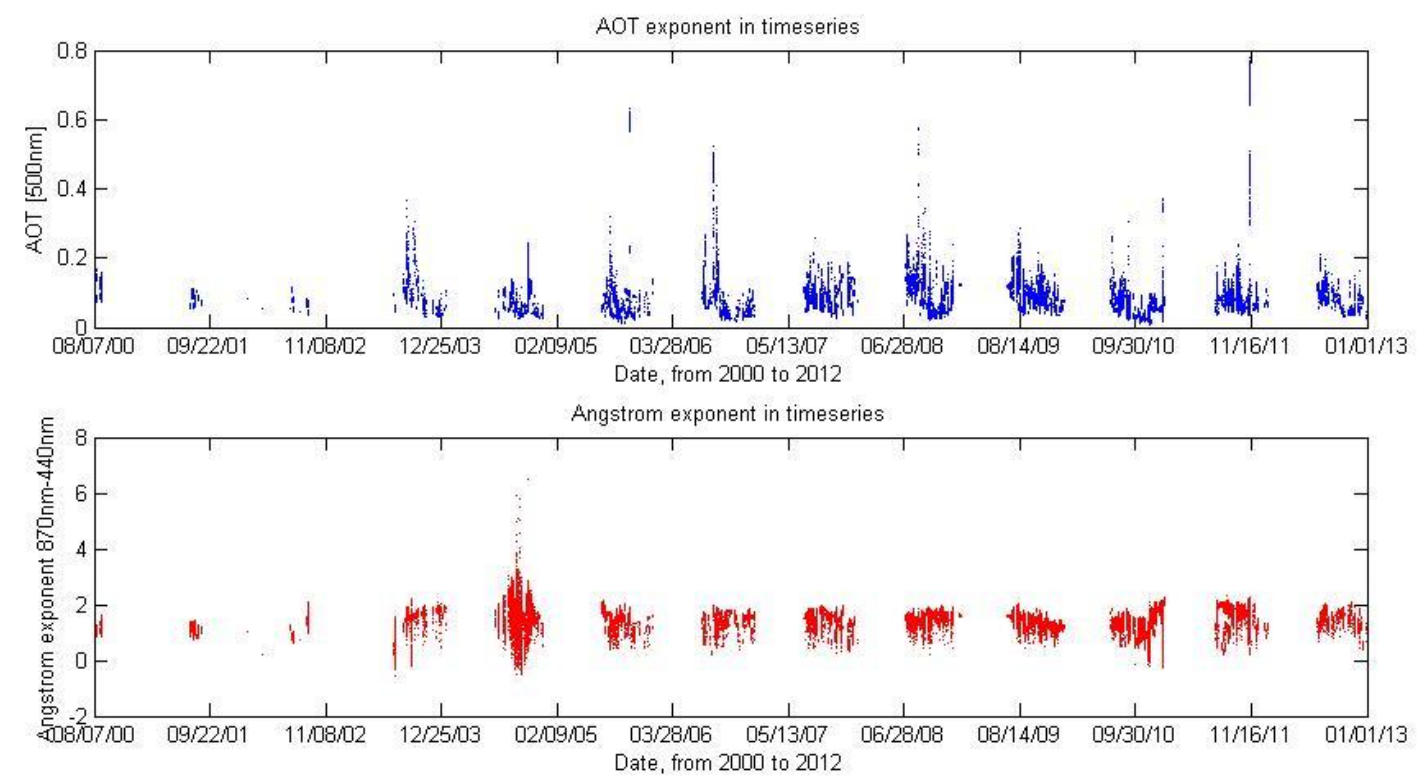

Figure 2. AOD (500 nm) and AE for all three stations between 2000 and 2012.

The data show a natural temporal ordering which is related to seasonal changes of aerosol loads into the Svalbard region. The AOD decreases from the higher events during springs (mean for spring $\sim 0.085 \pm .046$ ) to more or less stable situation in summers (mean for summer $\sim 0.063 \pm 0.042$ ). There were no events during the years $2000-2002$, in these years we 
have clear occurrence of marine aerosols. Mean for those years vary as follows: $0.084 \pm 0.018$, while the Ångström exponent: $1.269 \pm 0.194$.

Anthropogenic contamination advected with air masses from midlatitudes reach the polar regions seasonally, especially in early spring and summertime. In extreme cases of such advections or due to photochemical transformations of locally observed aerosols we deal with the so-called Arctic Haze. Several studies have shown the occurrence of the phenomenon in 2005 and 2006 (Quin et al., 2007; Engval et al., 2008; Rozwadowska et al., 2010). The occurrence of the strongest events during summer 2004, 2010 and spring 2006, 2008 are classified as extreme events. Those high AOD values have been related to the inflow of continental air masses.

A general overview of the data gives the information that the Aerosol Optical Depth is much higher these years than a decade before. With respect to the Ångström Exponent, which almost always follows the AOD values, most of its higher values should be related to the anthropogenic influence. Each year the most frequent value oscillates around 1.2-1.5, but between 2001 and 2011 they went up from 0.732 to 1.835 .

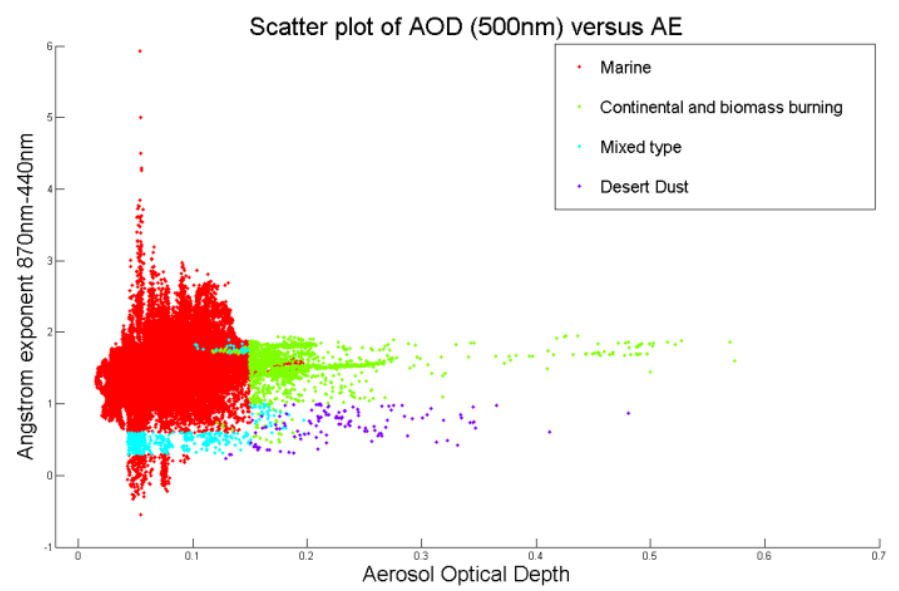

Figure 3. Scatter plot of AOD $(500 \mathrm{~nm})$ versus AE for all data from the discussed stations.

The independence of Aerosol Optical Depth and Ångström exponent illustrate the origin of aerosols. While AOD gives an information about the aerosol loading, the AE is related to aerosol size (type), both make an interpretation of the data. This nonlinear relationship between variables shows that marine is the most frequent source that can be observed, presented in a form of the largest concentration on the left-side of the plot within an entire spectrum of Ångström exponent and the AOD changing from 0 to 0.15 . The remaining part of AOD and AE spectra exceed 1, and this characterizes an anthropogenic source, such as e.g. biomass burning or continental type particles. The Ångström exponent below 1 - the desert dust and a mixed type, between these two sets. A statistical description of the AOD and AE data is provided in Table 2 below.

The basic statistics, which are presented in the table were calculated for all three stations. The extremes (minimum and maximum) and central tendency (mean) were used to present the changing aerosol structure with years and among the different locations. The variance measures how the parameters are spread out each year and almost for whole data it tends to be very close to the mean (small values). 
and among stations.

\begin{tabular}{|c|c|c|c|c|c|c|c|c|c|c|}
\hline \multirow{2}{*}{$\approx .0$} & \multirow{2}{*}{$\begin{array}{c}\mathrm{Nr} \text { of } \\
\text { pts. }\end{array}$} & \multirow{2}{*}{ Year } & \multicolumn{4}{|c|}{ AOD [500nm] } & \multicolumn{4}{|c|}{ Ångström exponent } \\
\hline & & & Minimum & Maximum & Mean \pm StD & Variance & Minimum & Maximum & Mean \pm StD & Variance \\
\hline \multirow{8}{*}{ 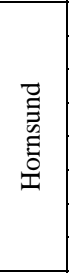 } & 853 & 2005 & 0.023 & 0.319 & $0.073 \pm 0.042$ & 0.002 & 0.370 & 1.793 & $1.148 \pm 0.277$ & 0.077 \\
\hline & 923 & 2006 & 0.022 & 0.522 & $0.111 \pm 0.099$ & 0.010 & 0.208 & 1.951 & $1.326 \pm 0.332$ & 0.110 \\
\hline & 1004 & 2007 & 0.037 & 0.256 & $0.089 \pm 0.032$ & 0.001 & 0.300 & 1.894 & $1.269 \pm 0.387$ & 0.150 \\
\hline & 1913 & 2008 & 0.023 & 0.574 & $0.102 \pm 0.055$ & 0.003 & 0.211 & 1.943 & $1.456 \pm 0.253$ & 0.064 \\
\hline & 1430 & 2009 & 0.041 & 0.285 & $0.104 \pm 0.039$ & 0.002 & 0.418 & 1.806 & $1.378 \pm 0.245$ & 0.060 \\
\hline & 401 & 2010 & 0.049 & 0.305 & $0.095 \pm 0.035$ & 0.001 & 0.499 & 1.877 & $1.234 \pm 0.338$ & 0.115 \\
\hline & 1534 & 2011 & 0.036 & 0.240 & $0.087 \pm 0.030$ & 0.001 & 0.235 & 1.977 & $1.371 \pm 0.419$ & 0.176 \\
\hline & 1336 & 2012 & 0.025 & 0.209 & $0.082 \pm 0.032$ & 0.001 & 0.391 & 2.105 & $1.561 \pm 0.271$ & 0.073 \\
\hline \multirow{2}{*}{$\therefore$ ㅊ } & 966 & 2003 & 0.029 & 0.365 & $0.095 \pm 0.060$ & 0.004 & 0.447 & 2.077 & $1.609 \pm 0.261$ & 0.068 \\
\hline & 491 & 2004 & 0.024 & 0.114 & $0.048 \pm 0.013$ & 0.000 & 0.491 & 1.839 & $1.357 \pm 0.251$ & 0.063 \\
\hline \multirow{12}{*}{ 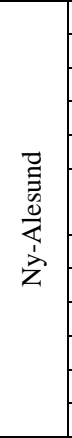 } & 1184 & 2000 & 0.073 & 0.195 & $0.110 \pm 0.025$ & 0.001 & 0.879 & 1.616 & $1.317 \pm 0.156$ & 0.024 \\
\hline & 2179 & 2001 & 0.053 & 0.110 & $0.077 \pm 0.016$ & 0.000 & 0.206 & 1.432 & $1.093 \pm 0.148$ & 0.022 \\
\hline & 1233 & 2002 & 0.037 & 0.115 & $0.066 \pm 0.015$ & 0.000 & 0.619 & 2.080 & $1.399 \pm 0.279$ & 0.078 \\
\hline & 888 & 2003 & 0.044 & 0.139 & $0.067 \pm 0.015$ & 0.000 & -0.185 & 2.164 & $0.755 \pm 0.519$ & 0.269 \\
\hline & 10515 & 2004 & 0.027 & 0.245 & $0.088 \pm 0.046$ & 0.002 & -0.192 & 2.318 & $1.609 \pm 0.485$ & 0.235 \\
\hline & 2499 & 2005 & 0.016 & 0.633 & $0.106 \pm 0.093$ & 0.009 & 0.313 & 2.317 & $1.334 \pm 0.369$ & 0.136 \\
\hline & 7039 & 2006 & 0.017 & 0.264 & $0.062 \pm 0.035$ & 0.001 & 0.535 & 1.802 & $1.493 \pm 0.189$ & 0.036 \\
\hline & 18442 & 2007 & 0.028 & 0.189 & $0.075 \pm 0.032$ & 0.001 & 1.025 & 1.937 & $1.580 \pm 0.164$ & 0.027 \\
\hline & 16239 & 2008 & 0.025 & 0.183 & $0.078 \pm 0.038$ & 0.001 & 1.046 & 1.875 & $1.536 \pm 0.153$ & 0.023 \\
\hline & 29862 & 2009 & 0.035 & 0.208 & $0.089 \pm 0.032$ & 0.001 & 0.773 & 1.995 & $1.360 \pm 0.243$ & 0.059 \\
\hline & 28935 & 2010 & 0.006 & 0.126 & $0.049 \pm 0.021$ & 0.000 & -0.163 & 2.237 & $1.382 \pm 0.319$ & 0.102 \\
\hline & 26021 & 2011 & 0.035 & 0.162 & $0.067 \pm 0.020$ & 0.000 & 1.065 & 2.234 & $1.835 \pm 0.147$ & 0.022 \\
\hline
\end{tabular}

\section{Conclusions}

In this work we have discussed the changes of aerosol optical depth (AOD) at $500 \mathrm{~nm}$ and the Ångström exponent (AE) (440-870 nm) measured with use of different types of sun photometers. A general conclusion is that the results obtained over a period of 2000 and 2012 show that marine source has been a dominating of aerosol sources over Spitsbergen. Some years $(2005,2006,2008$ and 2011) show very high values of AOD due to strong aerosol events such as the Arctic Haze. In general the mean AOD values increase over the period of 2000 and 2012 over Spitsbergen. This may indicate the presence of larger scale of atmospheric pollution in the region. This conclusion has to be further verified by applying of chemical composition analyses.

\section{Acknowledgements}

This research has been partly made within the framework of a Polish-Norwegian Research Programme operated by the National Centre for Research and Development under the Norwegian Financial Mechanism 2009-2014 in the frame of Project Contract No PolNor/196911/38/2013., part of the Polish-Norwegian Research Programme , partly within the scope of the GAME project and the KNOW (National Scientific Leading Centre).

\section{References}

Brock C. A., Cozic J., Bahreini R., Froyd K. D., Middlebrook A. M., McComiskey A., Brioude, J., Cooper O. R., Stohl A., Aikin K. C., de Gouw J. A., Fahey D. W., Ferrare R. A., Gao R.-S., Gore W., Holloway J. S., H“ubler G., Jefferson A., Lack D. A., Lance S., Moore R. H., Murphy D. M., Nenes A., Novelli P. C., Nowak J. B., Ogren J. A., Peischl J., Pierce R. B., Pilewskie P., Quinn P. K., Ryerson T. B., Schmidt K. S., 
Schwarz J. P., Sodemann H., Spackman J. R., Stark H., Thomson D. S., Thornberry T., Veres P.,Watts L. A.,Warneke C., Wollny A. G., 2011: Characteristics, sources, and transport of aerosols measured in spring 2008 during the aerosol, radiation, and cloud processes affecting Arctic Climate (ARCPAC) Project, Atmos. Chem. Phys., 11, 2423-2453, doi:10.5194/acp-11-2423-2011.

Dixon G. J., 1998, Laser Radars Produce Three-Dimensional Pictures, Laser Focus World, 4, 129-136.

Drollette D., 2000, Ancient Writings Come to Light, Photonics Spectra, 4, 40.

Dubovik O., Holben B., Eck T.F., Smirnov A., Kaufman Y.J., King M.D., Tanré D., Slutsker I., 2002, Variability of absorption and optical properties of key aerosol types observed in worldwide locations, J. Atmos. Sci. 59, 3, 590-608, DOI: 10.1175/15200469(2002)059<0590: VOAAOP>2.0.CO;.

Engvall A.-C., Krejci R., Str"om J., Treffeisen R., Scheele R., Hermansen O., Paatero J., 2008, Changes in aerosol properties during spring-summer period in the Arctic troposphere, Atmos. Chem. Phys., 8, 445-462, http://www.atmos-chemphys.net/8/445/2008/.

Fisher J. A., Jacob D. J., Purdy M. T., Kopacz M., Le Sager,P., Carouge C., Holmes C. D., Yantosca R. M., Batchelor R. L., Strong K., Diskin G. S., Fuelberg H. E., Holloway J. S., Hyer E. J., McMillan W. W., Warner J., Streets D. G., Zhang Q., Wang Y., and Wu S. , 2010, Source attribution and interannual variability of Arctic pollution in spring constrained by aircraft (ARCTAS, ARCPAC) and satellite (AIRS) observations of carbon monoxide, Atmos. Chem. Phys., 10, 977-996, doi:10.5194/acp-10-977-2010.

Heintzenberg J., Tuch T., Wehner B., Wiedensohler A., Wex H., Ansmann A., Mattis 1., Muller D., Wendisch M., Eckhardt S., Stohl A., 2003, Arctic haze over Central Europe, Tellus Series B-Chemical and Physical Meteorology 55 (3): 796-807

Herber A., Thomason L. W., Gernandt H., Leiterer U., Nagel D., Schulz K. H., Kaptur J., Albrecht T., Notholt J., 2002, Continuous day and night aerosol optical depth observations in the Arctic between 1991 and 1999, J. Geophys. Res., 107(D10), 4097, doi:10.1029/2001JD000536.

Herber A., Thomason L.W., Gernandt H., Leiterer U., Nagel D., Schulz K. H., Kaptur J., Albrecht T., Notholt J., 2002, Continuous day and night aerosol optical depth observations in the Arctic between 1991 and 1999. J. Geophys. Res., 107 D10, 10.1029/2001JD000536 - AAC 6-1 to 6-14.

Holben B. N., Eck T. F., Slutsker I., Tanre D., Buis J. P., Setzer A., Vermote E., Reagan J. A., Kaufman Y. J., Nakajima T., Lavenu F., Jankowiak I., Smirnov A., 1998, AERONET - a federated instrument network and data archive for aerosol characterization. Remote Sens. Environ., 66, 1-16.

Hudson S. R., 2011, Estimating the global radiative impact of the sea ice-albedo feedback in the Arctic, J. Geophys. Res.-Atmos., 116, D16102, doi:10.1029/2011JD015804. 
Ichoku C., Levy R., Kaufman Y.J., Remer L.A., Li1 R., Martins V.J., Holben B.N., Abuhassan N., Slutsker I., Thomas F. Eck,Christophe Pietras, 2002,Analysis of the performance characteristics of the five-channel Microtops II Sun photometer for measuring aerosol optical depth and precipitable water vapor, J. Geophys. Res., 107(D13), doi:10.1029/2001JD001302.

Labow G., 1996, Estimation of ozone with total ozone portable spectroradiometer instruments. II Practical operation and comparisons, Appl.Opt. 35, 6084-6089.

Markowicz K. M., Flatau P. J., Kardas A. E., Remiszewska J., Stelmaszczyk K., Woeste L., 2008, Ceilometer retrieval of the boundary layer vertical aerosol extinction structure, Journal of Atmospheric and Oceanic Technology, 25 (6): 928-944.

Markowicz K. M., Zielinski T., Blindheim S., Gausa M., Jagodnicka A. K., Kardas A., Kumala W., Malinowski S. P., Petelski T., Posyniak M., Stacewicz T., 2012, Study of vertical structure of aerosol optical properties with Sun photometers and ceilometer during MACRON Campaign in 2007, Acta Geophysica, 60 (5): 1308-1337.

Mazzola M., Stone R.S., Herber A., Tomasi C., Lupi A., Vitale V., Lanconelli C., Toledano C., Cachorro V.E., O’Neill N.T., Shiobara M., Aaltonen V., Stebel K., Zielinski T., Petelski T., Ortiz de Galisteo J.P., Torres B., Berjon A., Goloub P., Li Z., Blarel L., Abboudm I., Cuevas E., Stock M., Schulz K.-H., Virkkula A., 2012, Evaluation of sun photometer capabilities for retrievals of aerosol optical depth at high latitudes: The POLAR-AOD intercomparison campaigns, Atmospheric Environment, 52: 4-17 Sp. Iss. SI JUN 2012,

Morys M., Mims III F.M., Hagerup S., Anderson S. E., Baker A., Kia J., and Walkup T., 2001, Design, calibration, and performance of Microtops II handheld ozone monitor and Sun photometer. J.Geophys. Res., 106, 14,573-14,582.

Petelski T., Markuszewski P., Makuch P., Jankowski A., Rozwadowska A., 2014. Studies of vertical coarse aersol fluxes In the Bondary layer over the Baltic Sea, Oceanologia 56 (4), 2014, pp. 697-710, doi:10.5697/oc.56-4.697.

Petelski T., Piskozub J. , 2006, Vertical coarse aerosol fluxes in the atmospheric surface layer over the North Polar Waters of the Atlantic, J. Geophys. Res., 111, C06039, doi:10.1029/2005JC003295.

Quinn P. K., Shaw G., Andrews E., Dutton E. G., Ruoho-Airola T., Gong S. L. , 2007, Arctic haze: current trends and knowledge gaps, Tellus, 59B, 99-114.

Quinn P. K., Shaw G., Andrews E., Dutton E. G., Ruoho-Airola T., Gong S. L., 2007, Arctic haze: current trends and knowledge gaps. Tellus B, 59(1), 99-114. doi:10.1111/j.16000889.2006.00238.x

Rozwadowska A., Sobolewski P., 2010, Variability in aerosol optical properties at Hornsund, Spitsbergen, Oceanologia 2010, no. 52(4), pp. 599-620 doi:10.5697/oc.52-4.599.

Rozwadowska A., Górecka I., 2012, The impact of a non-uniform land surface on the radiation environment over an Arctic fjord - a study with a 3D radiative transfer model 
for stratus clouds over the Hornsund fjord, Spitsbergen , Oceanologia 2012, no. 54(4), pp. 509-543, doi:10.5697/oc.54-4.509

Rozwadowska A., Zieliński T., Petelski T., Sobolewski P., 2010, Cluster analysis of the impact of air back-trajectories on aerosol optical properties at Hornsund, Spitsbergen. Atmospheric Chemistry and Physics, 10(3), 877-893. doi:10.5194/acp-10-877-2010

Shaw G. E., 1976, Error analysis of multi-wavelength Sun photometry, Pure Appl. Geophys., $114,1-14$.

Smimov A., Holben B.N., Eck T.F., Dubovik O., 2000, Cloud-Screening and quality control algorithms for the AERONET database. Remote Sens. Environ. 73, 337-349.

Smirnov A., Holben B. N., Eck T. F., Dubovik O., Slutsker I., 2000, Cloud-screening and quality control algorithms for the AERONET database. Remote Sens. Environ., 73, 337-349.

Smirnov A., Holben B. N., Eck T. F., Slutsker I., Chatenet B., Pinker R. T., 2002, Diurnal variability of aerosol optical depth observed at AERONET (Aerosol Robotic Network) sites, Geophys. Res. Lett. , 29 (23), 2115, doi:10.1029/2002GL016305.

Stohl A., 2006, Characteristics of atmospheric transport into the Arctic troposphere, J. Geophys. Res.-Atmos., 111, D11306,doi:10.1029/2005jd006888.

Toledano C., Cachorro V., Gausa M., Stebel K., Aaltonen V., Berjon A., Ortis J. P., de Frutos A. M., Bennouna Y., Blindheim S., Myhre C. L., Zibordi G., Wehrli C., Kratzer S., Hakanson B., Carlund T., de Leuww G., Herber A., 2012, Overview of Sun photometer measurements of aerosol properties in Scandinavia and Svalbard, Atmospheric Environment., 52 , pp. 18-28 . doi: 10.1016/j.atmosenv.2011.10.022

Tomasi C., Vitale V., Lupi A., Di Carmine C., Campanelli M., Herber A., Treffeisen R., Stone R. S., Andrews E., Sharma S., Radionov V., von Hoyningen-Huene W., Stebel K., Hansen G. H., Myhre C. L., Wehrli C., Aaltonen V., Lihavainen H., Virkkula A., Hillamo R., Stroem J., Toledano C., Cachorro V. E., Ortiz P., de Frutos A. M., Blindheim S., Frioud M., Gausa M., Zielinski T., Petelski T., Yamanouchi T., 2007, Aerosols in polar regions: A historical overview based on optical depth and in situ observations, J. Geophys. Res., 112, D16205, doi:10.1029/2007JD008432.

Treffeisen R., Herber A., Ström J., Shiobara M., Yamanouchi T., Yamagata S., Holmén K., Kriew M., \& Schrems O., 2011, Interpretation of Arctic aerosol properties using cluster analysis applied to observations in the Svalbard area. Tellus B, 56(5). doi:10.3402/tellusb.v56i5.16469.

Zawadzka O., Makuch P., Markowicz K.M., Zielinski T., Petelski T., Ulevicius V., Strzalkowska A., Rozwadowska A., Gutowska D., 2014, Studies of aerosol optical depth with use of Microtops sun photometers and MODIS detectors in the coastal areas of the Baltic Sea, Acta Geophysica, , vol. 62, no. 2, Apr. 2014, pp. 400-422, DOI: 10.2478/s11600-013-0182-5, 2014. 
1 Zielinski T., 2004, Studies of aerosol physical properties in coastal areas. Aerosol $2 \quad$ Science\&Technology, 38 (5): 513-524,

3 Zielinski T., Petelski T., Makuch P., Strzalkowska A., Ponczkowska A.,. Markowicz K. M, 4 Chourdakis G., Georgoussis G., Kratzer S., 2012, Studies of aerosols advected to 5 coastal areas with use of remote techniques, Acta Geophysica, vol. 60, no. 5, DOI: $6 \quad 10.2478 / \mathrm{s} 11600-011-0075-4,1359-1385$.

7 